\title{
Negligent Sexual Assault: \\ Reform Of The Criminal Law And A Tort Alternative
}

\author{
Richard Sawyer and Tom Tian*
}

\section{I - Introduction}

Prior to 2007, there was no s61HA of the Crimes Act 1900 (NSW). At that time, to successfully convict an accused for sexual assault, the prosecution had to establish three things beyond reasonable doubt. First, that sexual intercourse had taken place; second, that the complainant did not consent to that sexual intercourse; and third, a mens rea or 'knowledge' requirement. To discharge their onus regarding this last limb, the prosecution had to prove that the defendant either knew the complainant was not consenting or was reckless as to consent.

The result was that, at least in theory, a defendant who could establish a subjective belief that a sexual partner was consenting would be acquitted, no matter how unreasonable that belief. The defendant, you could say, lived or died on his or her own subjective mental state: their culpability was tied almost entirely to their consciousness of guilt. As a result, those who endured non-consensual sex with a person who had an honest but unreasonable belief that the sex was consensual were left without recourse in the criminal law for the harm done to them. Some might say that their 'right' to see their assailants punished was not protected by the criminal law.

\footnotetext{
* Richard and Tom are candidates for the BA/LLB at the University of Sydney. Both are passionate about criminal law.
} 
In this article, we consider the legislative attempt at closing this gap in the form of the Crimes Amendment (Consent - Sexual Assault) Offences Act 2007 (NSW), which added the new s61HA and, with it, an objective approach to the requisite mens rea. We contrast this solution with our own alternative model based in tort law, which, while suffering from its own problems, provides a useful theoretical contrast to the approach taken by the legislature.

In imposing an objective mens rea requirement for sexual assault, the legislature has attempted to solve complex and important problems within the existing state of the law. However, by advancing the reforms as part of a progressive or feminist-inspired movement toward justice for victims, they have placed the reforms at the heart of controversial terrain. The result may be that critiques of the reform appear unsympathetic to those who have endured sexual assault. Yet this should not circumscribe a full and frank analysis of the implications of the reform. If reforms, motivated by admirable aims, fail to achieve substantive justice, they should not be fully endorsed, even by authors who would otherwise be sympathetic to such theoretical or political positions (such as the authors of this article).

Our thesis is that approaching reform of the criminal law with a primary preoccupation with the harm suffered by a victim will inevitably cause controversy and dissatisfaction. This is because the criminal law has traditionally focused on the guilt or innocence of an accused. Our alternative model, utilising tort law, does not require reform of the law because it relies on the legal distinction, inherent in the criminal and civil systems, between tort law's focus on the victim and criminal law's focus on the accused. In any event, as we shall endeavour to demonstrate, by creating an objective mens rea standard for sexual assault, the reforms may have unwittingly cemented the position of the actions of the victim at the heart of the jury's investigation, resulting in outcomes that reinforce rather than alter unjustified claims that sexual assault occurs because of the actions of victims. 


\section{II - The 2007 Amendments}

In 2007, the Crimes Amendment (Consent - Sexual Assault) Offences Act 2007 (NSW) amended the Crimes Act 1900 (NSW) to add a new s61HA. This section performs a number of functions relating to the offence of sexual assault. ${ }^{1}$ This article shall only discuss s61HA(3)(c) and its introduction of an objective mens rea for sexual assault.

Where a defendant now claims that he or she thought their sexual partner was consenting, a jury will be asked to determine whether they had reasonable grounds for that belief. If the jury finds they had no reasonable grounds, the defendant will be treated as if they knew the complainant was not consenting. The subsection thereby augments the mens rea for sexual assault to catch those aforementioned defendants who held an honest but unreasonable belief that a sexual partner was consenting to sexual intercourse. The practical effect is that those who have sexual intercourse with another person, believing that they are consenting, may nonetheless be liable for sexual assault charges.

The section works through something of a legal artifice: imposing on a defendant an artificial state of knowledge in response to the unreasonableness of their real state of mind. This mens rea requirement is thus 'objective' since it discards the subjective mind state of the defendant for an inquiry into whether a person such as the defendant, sharing the defendant's belief, would hold their belief on reasonable grounds.

In determining whether the defendant had reasonable grounds, juries are to have regard to all the circumstances of the case and particularly any steps that the defendant took to ascertain whether the complainant was consenting. ${ }^{2}$ An appellate court has yet to interpret the effect of this new section and there remain significant questions as to its proper operation. ${ }^{3}$

\footnotetext{
${ }^{1}$ For a detailed overview, see Ian Dobinson and Lesley Townsley, 'Sexual Assault Law Reform in NSW: Issues of Consent and Objective Fault' (2008) 32 Criminal Law Journal 152.

${ }^{2}$ Crimes Act 1900 (NSW) s61HA(3)(d). Juries may not, however, have regard to the self-induced intoxication of the defendant: Crimes Act 1900 (NSW) s61HA(3)(e).
}

Public Space: The Journal of Law and Social Justice (2009) Vol 4, pp 105-121 
It is clear from the Bill's second reading speech that the reforms had a number of aims. First, the reforms sought to address the 70 recommendations of a report by the Criminal Justice Sexual Offences Task Force, as well as concerns raised by providers of women's legal services, rape crisis services and more collectively those representing women's interests. Secondly, the new law was to play a socially educative role - encouraging active ascertainment of consent before sexual intercourse and helping to bring about a cultural change in the investigation and prosecution of sexual assault. Thirdly, the reforms aimed to introduce community standards into determining the culpability of defendants in sexual assault trials. Fourthly, they were to help 'alleviate the high rates of attrition in sexual offence' trials and address low conviction rates for sexual assault. Last, the Attorney-General referred to simplifying the criminal trial process for juries, by allowing them to employ their common sense to determine liability. ${ }^{4}$

Many of these aims are admirable, particularly the stated aim of attempting to address low conviction rates for sexual assault and we do not suggest that the law as it stood before the reform was satisfactory. Nonetheless, the specific form that the reforms have taken places them at odds with how the criminal law has historically attributed liability. It has been suggested that in recognition of this, the objective mens rea offence should be a separate offence, with a different maximum sentence. We shall assess the implications of accepting this route. Finally, we suggest that a negligent standard of sexual assault in the context of the criminal trial may in fact legitimise rather than attack pre-existing suppositions made by juries that the actions of a victim play a causative role in sexual assault. If this is the case, then the reforms have not achieved their aims of better substantive justice for victims. We shall discuss some of these concerns before turning our attention to our alternative model for addressing negligent sexual assault in tort law.

\footnotetext{
${ }^{3}$ Dobinson and Townsley, above n 1, 159-65.

${ }^{4}$ New South Wales, Second Reading Speech, Legislative Council, 7 November 2007, 3584 (John Hatzistergos, NSW Attorney-General and Minister for Justice).
}

Public Space: The Journal of Law and Social Justice (2009) Vol 4, pp 105-121 


\section{A - An Objective Mens Rea}

The concept of an objective mens rea standard in the criminal law is controversial. This is despite the fact that examples of its existence are readily at hand: manslaughter by reason of criminal negligence or causing grievous bodily harm by negligent act, being just two examples.

Traditionally, criminal culpability has been connected conceptually to the guilty mind of the defendant. Such a principle was as clear in Lord Coke's 17th Century maxim actus no facit eum nisi mens sit rea - that is, an act does not make someone guilty unless their mind is also guilty - as it remained in the early 20th Century formulation proffered by C S Kenny that "no external conduct, however serious or even fatal its consequences may have been, is ever punished unless it is produced by some form of mens rea' 5

One major justification for a focus on such subjectivism has been that the development of mens rea requirements in the criminal law was a civilising move away from an unjust focus on the actus reus alone that may have characterised criminal law systems of the past. In this way, for some, mens rea requirements play a significant role in contemporary justifications for criminal punishment, legitimising the intervention of the State into the lives of citizens. ${ }^{6}$

Of course, this narrative of gradual if inevitable progress is overly simplistic. Defendants can be found guilty of a crime without knowledge of the content of the law, for example, as ignorance of the law is said never to excuse a defendant. Similarly, arguably, with latemodernity has come the invention of new strict liability crimes, such as those relating to

\footnotetext{
${ }^{5}$ C S Kenny, Outlines of Criminal Law (2 ${ }^{\text {nd }}$ Ed, 1904) 39.

${ }^{6}$ See, for a fuller discussion of this historical aspect, Nicola Lacey, 'Responsibility and Modernity in Criminal Law' (2000) 9 Journal of Political Philosophy 249; George P Fletcher, Rethinking Criminal Law (2000); David Cairns, Advocacy and the Making of the Adversarial Criminal Trial, 1800-1865 (1998); John H Langbein, The Origins of the Adversary Criminal Trial (2003).
}

Public Space: The Journal of Law and Social Justice (2009) Vol 4, pp 105-121 
environmental pollution. ${ }^{7}$ And, of course, the mens rea requirement of recklessness includes situations where an accused did not even consider a particular risk at all. ${ }^{8}$

Nevertheless, so-called 'objective mens rea' requirements do not sit well with this traditional focus on culpability through a guilty mind. Thus, the presumption remains that absent contrary statutory intent, a 'mens rea, an evil intention, or a knowledge of the wrongfulness of the act, is an essential ingredient in every offence'. ${ }^{9}$ As Chief Justice Bray strongly argued in the context of criminal battery:

"[i]t is contrary to fundamental principles and the whole tenor of modern thought to judge a man in a criminal court ... not by his actual intention, knowledge or foresight, but by what a reasonable and prudent man would have intended, known or foreseen in the circumstances. $" 10$

Such distaste for objective tests may arise from the peculiar severity of the criminal jurisdiction. As the Lord Chancellor, Lord Irvine of Lairg, has argued:

"The State can deliver no stronger condemnation than a finding of criminal guilt. Its reach can extend beyond the punishment itself - to loss of employment, or professional status, or even the freedom to travel abroad. These extra-judicial consequences record the social truth that, implicit in a criminal conviction, is the judgment that the defendant has done something reprehensible, warranting serious moral blame. Ultimately, it is the implicit moral condemnation in a conviction that gives the word 'criminal' its cultural resonance." 11

\footnotetext{
${ }^{7}$ For example, Protection of the Environment Operations Act 1997 (NSW) s 116.

${ }^{8} R v$ Kitchener (1993) 29 NSWLR 696; affirmed in Banditt $v$ The Queen (2005) 224 CLR 262.

${ }^{9}$ Sherras v De Rutzen (1895) 1 QB 918, 921; affirmed in He Kaw Teh v R (1985) 157 CLR 523.

${ }^{10}$ MacPherson v Brown (1975) 12 SASR 184, 188 (Bray CJ).

${ }^{11}$ The Right Honourable Lord Irvine of Lairg, Lard Chancellor, 'Intention, Recklessness and Moral Blameworthiness: Reflections on the English and Australian Law of Criminal Culpability' (2001) 23 Sydney Law Review 5, 6.
} 
A major concern with the new amendments and notions of objective fault is that they fail to distinguish between people acting intentionally or recklessly and those that have merely taken less care than the reasonable person. There are clearly two different levels of moral culpability, but under the current law they are treated the same.

The typical response of legislatures in creating offences with an objective mens rea has been to recognise a lower level of culpability through the provision of significantly lower maximum penalties. We shall consider the possibility of a separate offence of negligent sexual assault below.

\section{B - Two Levels of Culpability}

The taskforce briefly considered a suggestion to introduce a separate offence with a lower maximum penalty for sexual assaults in which the defendant had an honest but unreasonable belief the complainant was consenting. The suggestion was to include a s61IA:

"Any person who has sexual intercourse with another person without the consent of the other person and who fails to take reasonable steps to ascertain whether the other person consented, is liable to imprisonment for 5 years. "12

Among the benefits of this suggestion were to avoid the problem which arises under the current system, whereby the sentencing judge may be left unaware of the jury's grounds for conviction (although to some extent the culpability of the accused could be taken into account on sentencing without having separate offences). In addition, other ramifications associated with the label of an offence may fail to take into account the lesser level of culpability, such as blacklisting through a criminal record and offender registries. ${ }^{13}$

\footnotetext{
${ }^{12}$ Criminal Law Review Division, The Law of Consent and Sexual Assault, Discussion Paper (AttorneyGeneral's Department NSW, 2007).

${ }^{13}$ For a discussion on the effect of 'labelling' see, Thomas Crofts, 'Two Degrees of Murder: Homicide Law Reform in England and Western Australia' (2008) 8 Oxford University Commonwealth Law Journal 187.
}

Public Space: The Journal of Law and Social Justice (2009) Vol 4, pp 105-121 
One concern with this suggestion has been that having separate offences may lead to compromised verdicts, as juries opt to take the lesser statutory offence. Surely though, this should not be a concern if we are to hold to a standard of proof that is beyond reasonable doubt.

A more compelling objection to the introduction of a second offence involving a lower level of culpability lies in the highly political debate about the rights of complainants. It is difficult to imagine how a lawyer might justify to a complainant why the attack on them deserved a lesser penalty: is rape not just rape? To the layperson, by separating assailants into different levels of culpability, complainants may possibly feel that they are likewise being ranked. Evidence surrounding the complainant's behaviour is likely to enter the court room, and the result might appear to be that some complainants had led their assailants on. Would the message be that some complainants are virtuous and have been raped, while others should exercise more responsibility for their actions?

At a formal level, this objection rests on an inaccurate impression of criminal justice. Strictly speaking, the criminal law judges the actions and intentions of the accused, and makes no statement regarding the behaviour of the complainant. The verdict reveals that the defendant did not have reasonable grounds to believe the complainant was consenting. The trouble is, in the murkiness of a sexual assault trial, the practical effect might still be the separation of complainants into categories. These are only possibilities, and of course, arguments guessing public reaction and assumptions about lay opinions are weak. However, it warrants consideration whether the possible harm caused to complainants may not be commensurate with a more appropriate label for the defendant's crime.

This is an old issue arising from the conflict between lay perceptions of the criminal law, and what the law tells itself. It manifests in the politically charged question: to what extent are a complainant's interests taken into account during the criminal justice process? Criminal justice has always erred on the side of the defendant. This is necessarily so, as a check on the courts' power to deprive an accused of their liberty - they cannot lock away the complainant. 


\section{C - Reasonable grounds: The Victim on Trial?}

In either the legislation's current form, or in a graduated liability structure, negligent sexual assault trials may have the opposite effect on a complainant's experience of justice than that anticipated by the legislature. It may be that in its attempt to extend further protection to complainants of sexual assault, the legislature has inadvertently created a situation in which a complainant's actions will become the primary focus of sexual assault trials.

Where a defendant claims they believed a complainant was consenting to sex, the jury is required to have regard to 'all the circumstances of the case' in determining whether there were reasonable grounds for that belief. Naturally, the words and conduct of the complainant preceding sexual intercourse are likely to be included for examination. In addition, facts the defendant knew about the complainant and even things the defendant had heard about the complainant could be considered relevant to determining whether the defendant had reasonable grounds for their belief.

At present, the extent to which the subjective features of the defendant may be taken into account in determining whether they had reasonable grounds is something that is yet to be determined. ${ }^{14}$ As a result, the exact evidence that may be taken into account in making the jury's determination remains unclear, but enough is clear to show that the jury will be, to a large degree, passing judgment on the actions of the complainant as much as the actions of the defendant.

Where a jury finds that a defendant's belief that a complainant was consenting was reasonable, the jury will be in effect concluding that it was the actions of the complainant which brought about the sexual assault. Defence barristers, more than ever, will be encouraged by the law to argue that any reasonable person, faced with the actions of the

\footnotetext{
${ }^{14}$ See generally, Dobinson and Townsley, above $\mathrm{n} 1$.
} 
complainant and their history, would have concluded they were consenting. Trials turning on such archaic notions would be a travesty. It may be commented that at least in practical terms the position did not differ before the amendments. Nonetheless, the distinction after the reforms is that the law now actively encourages juries to engage in this form of reasoning, giving them a duty to consider 'all the circumstances of the case' in measuring the grounds for the defendant's belief. The view that some victims may contribute to their sexual assault is now ingrained in the letter of the law.

Yet in introducing the legislation, the Attorney-General John Hatzistergos stressed the difficulties that complainants already face with jurors who continue to hold 'stereotypical beliefs about rape and its victims'. He cited a study by the Australian Institute of Criminology that revealed that 'juror judgments in rape trials are influenced more by the attitudes, beliefs and biases about rape that jurors bring with them into the courtroom than by the objective facts presented'. Some jurors, he continued, "still hold the view that women often say "no" when they mean "yes", that women who are raped often ask for it, and that rape results from men not being able to control their need for sex and responsibility for rape is therefore removed'. ${ }^{15}$ It may be a cruel twist of irony that the government's attempts to change juror attitudes in fact give their existing attitudes a more powerful role in resolving sexual assault trials.

\section{III - A Tort of Sexual Assault}

In cases of negligent sexual assault, reality becomes splintered. There are two alternative experiences of one event: for the defendant, it was consensual sex; while for the complainant, it was sexual assault. Unlike other legal disputes where one single factual account can be distilled and conflict arises over the application of legal principles, here the law is being asked to intervene in a space between subjective realities. The dispute sharply reveals the

\footnotetext{
${ }^{15}$ New South Wales, Second Reading Speech, Legislative Council, 7 November 2007, 3584 (John Hatzistergos, NSW Attorney-General and Minister for Justice).
}

Public Space: The Journal of Law and Social Justice (2009) Vol 4, pp 105-121 
potential inadequacy of a 'rights' based discourse. ${ }^{16}$ Both defendant and complainant could be said to have rights: collectively, victims' rights or defendants' rights; more specifically, the right to have one's harm addressed by the law, conflicting with the right of an accused to be judged by their own guilty mind. The identification of rights in conflict arguably does little to promote solutions to harmonise those rights.

The injustice of the law before the amendment was centred on the complainant's unaddressed harm, not on any guilty mind of the criminal. To us, such a focus resembled the preoccupations of tort law more than those of criminal law. Could tort law be used to address the harm suffered by the complainant, without moving criminal law away from its traditional focus on a subjective guilty mind? What we propose is a tort of sexual assault: a civil penalty for negligent sexual assault.

Apart from offering a more theoretically-accordant basis for remedies, a tort of sexual assault would have a number of key benefits for complainants. The tort would bolster the court's public denouncement of the defendant's actions. Defendants would face social consequences as their behaviour is publicised which, along with the pecuniary penalty, would generate public disapproval of the behaviour. In addition, and also in favour of complainants, the problem of conservative juries already discussed would be eradicated from tort cases. Hopefully, under the gaze of a judge, determinations would be made more objectively and free from such outdated conceptions. Similarly, complainants would avoid the difficulties of the very high standard of proof required in the criminal law, as their case would be subject instead to a 'balance of probabilities' standard applicable in the civil law. Where complainants lack corroborative evidence, it is practically difficult in criminal trials for prosecutors to establish the facts of their case beyond a reasonable doubt against the word of a defendant. A tort of sexual assault would alleviate this difficulty.

\footnotetext{
16 See also, Helen Irving, 'Rights and Citizenship in Law and Public Discourse' in Tom Campbell, Jeffrey Goldsworthy and Adrienne Stone (eds), Protecting Rights Without a Bill of Rights: Institutional Performance and Reform in Australia (2006) 161.
}

Public Space: The Journal of Law and Social Justice (2009) Vol 4, pp 105-121 
At least technically, liability in tort for sexual assault would not need to stem from the creation of any new, discrete tort. Plaintiffs might already bring a complaint of sexual assault through battery, or, as seen in some existing case law, in negligence. It is through these existing structures of tort law that we now turn to explore the tort of sexual assault.

\section{A - Battery}

Battery is the most attractive civil remedy available to a complainant of sexual assault as a result of the operation of onuses of proof. Battery is a trespass to the person whereby the defendant causes physical contact with the plaintiff. In Australia, a plaintiff must merely establish the fact that contact occurred for an action of battery to lie.

In an action for battery in the civil law, consent is most likely a defence and must be proven by a defendant. This position is not uncontroversial in Australia. It has been argued that the absence of consent should be an element of battery, ${ }^{17}$ reflecting the position in England. ${ }^{18}$ However, the issue seems settled in Australia since McHugh J's strong statement in Marion's Case that the onus of proving consent must fall to the defendant. ${ }^{19}$ Justice McHugh argued that to find otherwise would be to fail to adequately recognise individual autonomy and the right to have control over one's body. ${ }^{20}$ This reasoning is clearly applicable in the context of sexual assault.

Accordingly, a defendant in action for battery arising out of sexual assault would have the onus of proving that their sexual partner consented to the sexual intercourse on the balance of

\footnotetext{
${ }^{17}$ Rosalie Balkin and Jim Davis, Law of Torts ( $3^{\text {rd }}$ Ed, 2004) 39; Sam Blay 'Onus of Proof of Consent in an Action for Trespass to the Person' (1987) 61 Australian Law Journal 25.

${ }^{18}$ Freeman v Home Office (No 2) [1983] 3 All ER 589, 594-5.

${ }^{19}$ Department of Health and Community Services $v$ JWB and SMB (Marion's Case) (1992) 175 CLR 218, 310 11 (McHugh J).

${ }^{20}$ Ibid.
}

Public Space: The Journal of Law and Social Justice (2009) Vol 4, pp 105-121 
probabilities. ${ }^{21}$ In contrast, consent is part of the actus reus under the criminal law and must be established by the prosecution. The change in the onus and burden of proof would be a procedural advantage to complainants under tort law.

\section{B - Negligence}

Under the current law of negligence, the plaintiff would need to establish a duty of care, breach of that duty and damage caused by the breach that is not too remote. It is still unclear in Australia whether acts amounting to intentional trespass can be pleaded as negligence. In sexual assault cases, the sex act is usually intentional, though the defendant may have been careless in ascertaining consent. The High Court has said in obiter that if the actions of a defendant were intentional, then the claim must be brought in trespass and not negligence. ${ }^{22}$ However, this was not followed by the Tasmanian Supreme Court in Wilson v Horne, where the plaintiff was allowed to sue in negligence for sexual assault. ${ }^{23}$ However, Wilson v Horne involved resurfaced memories of sexual abuse as a minor, which presented a different situation as consent was not an issue.

The law of negligence would need to be adapted to incorporate notions of consent for a tort of negligent sexual assault. People would owe a duty of care to ensure consent before engaging in sexual intercourse. This duty would be breached if the defendant had no reasonable grounds to believe the plaintiff was consenting. Causation of damage and remoteness could then follow the general law, being physical or psychological harm. ${ }^{24}$ Such a tort would mirror s61HA(3)(c) of the Crimes Act.

\footnotetext{
${ }^{21}$ Ibid.

${ }^{22}$ Williams v Milotin (1957) 97 CLR 465, 473.

${ }^{23}$ Graeme James Gregory Wilson v Cherie Jayne Horne [1999] TASSC 33 ('Wilson v Horne'). Leave to appeal this decision was rejected: Wilson v Horne (1999) 19 Leg Rep SL4a.

${ }^{24}$ Wilson v Horne [1999] TASSC 33.
}

Public Space: The Journal of Law and Social Justice (2009) Vol 4, pp 105-121 
For the reasons discussed above, a plaintiff might not recover under a tort of negligent sexual assault for intentional sexual assaults, and besides, the label of negligent sexual assault would be inappropriate. Without fundamental changes, negligence does not seem to be the right model on which to base a tort of sexual assault. While it seems apt to bring an action involving an objective standard in negligence, the language of consent is unfamiliar to negligence, while it is a defence to battery. The emphasis in battery is placed upon the disregard of human dignity, while negligence is more concerned with assessing the harm caused.

The tort of battery also has advantages in terms of the amount of damages recoverable by a plaintiff. The most obvious limitation on damages in negligence, the Civil Liability Act, does not apply to 'sexual misconduct'. ${ }^{25}$ Nevertheless, battery is actionable without any proof of damage. ${ }^{26}$ Under negligence, there might be difficulty establishing a recognised psychiatric illness. ${ }^{27}$ Aggravated damages may be awarded depending on the defendant's conduct, but exemplary damages are only likely to be awarded where the sexual assault was intentional. ${ }^{28}$

\section{C - Problems with a Tort of Sexual Assault}

There are major concerns with a tort claim for sexual assault. Perhaps most obviously is the extent to which damages might appropriately remedy the harm suffered in a sexual assault. This issue has both a philosophical and practical dimension. First, money may be seen as a vastly inadequate response to the non-financial damage occasioned by sexual assault.

Secondly, though, damages in tort are always first and foremost limited by the capacity of the tortfeasor to pay. Where tortfeasors are unable to pay, plaintiffs would be left with a claim against the victim's compensation fund. ${ }^{29}$ Further, the plaintiff plays a greater role in tort

\footnotetext{
${ }^{25}$ Civil Liability Act 2002 (NSW) s 3B.

${ }^{26}$ Battiato v Lagana [1992] 2 Qd R 234.

${ }^{27}$ Wilson v Horne (1999) 8 Tas R 363.

${ }^{28}$ Lamb v Contogno (1987) 164 CLR 1.

${ }^{29}$ Victims Support and Rehabilitation Act 1996 (NSW) sch 1, pt 6.
} 
claims, and in the case of negligence, this might further expose them to defences such as contributory negligence and voluntary assumption of risk. This would only place more emphasis upon the complainant's actions during trial, which risks replicating the problems currently experienced by sexual assault complainants. Last, the problems mentioned above that arise in the context of having two separate levels of liability (here, a criminal sanction and, alternatively, liability in tort) apply. It is possible that the existence of liability in tort, but not in criminal law, would ostensibly separate complainants into classes more or less responsible for their own harm.

The last issue will necessarily arise wherever the law attempts to protect both victim and accused in an uneasy legal compromise. The most that can be said in this regard is that the distinction between tort and criminal liability is perhaps the most appropriate line to draw to strike a balance between the rights of the victim and those of the accused. In the context of a criminal trial, the right of an accused to a fair trial is unchallengeable. The harm caused by a wrongful conviction prevents any true consideration of a victim's rights. The civil law is better able to juggle the competing rights of the victim and accused, as the defendant's liberty is not at stake.

\section{IV - Conclusions}

The issue of consent in the law of sexual assault highlights fundamental conflicts about who the criminal law should ultimately protect. The law as it stood before the introduction of s61HA led to injustice for some complainants of sexual assault; it did not recognise their 'right' to see their assailant punished. However, the legislature's solution in s61HA conflicts with historical and theoretical tenets of the criminal law regarding the culpability of accused persons. The criminal law has traditionally placed a greater emphasis upon the accused's right to be judged according to their subjectively guilty mind.

The insertion of an objective mens rea into sexual assault also fails to reflect different levels of moral culpability for negligent versus intentional or reckless sexual assault. A graded set of sexual assault offences would more appropriately match the crime to the level of moral 
culpability and is more in line with other negligent mens rea offences. Yet, such a set of offences may have the undesired effect of grading complainants. ${ }^{30}$ We have argued that this unfortunate outcome stems from attempts to utilise the criminal law to redress victims' harm, disregarding the important fact that the criminal law has traditionally focused on the culpability of the accused, not the harm caused to the victim.

We have raised the possibility of a separate tort of sexual assault that is more in line with traditional notions of criminal law yet still protects the complainant's rights. Tort liability for sexual assault is possible under existing tort law and offers a range of benefits for complainants, including with regards to the burden and onus of proof, as well as the problems currently experienced by victims when faced with conservative juries. However, tort remedies rely on there being a solvent offender to sue, may implicate complainants in counter claims and may similarly grade victims. While a tort of sexual assault is an unlikely contender for reform, it is nevertheless always useful to be reminded of the alternatives that lie beyond the boundaries of the criminal law and which may be more theoretically consistent in achieving the aims of policymakers. By focusing all of their efforts on reforming the criminal law in attempting to find justice for victims, legislators may have settled on a 'solution' that does not respect traditional legal distinctions and therefore will never satisfy all stakeholders.

\footnotetext{
${ }^{30}$ As to graded levels of rape, see discussion of 'real rape' in, for example, Lois Pineau, 'Date Rape: A Feminist Analysis' in Leslie Francis (ed), Date Rape: Feminism Philosophy, and the Law (1996) 1.
} 